\title{
The effect of sulphur deficiency and sulphur fertilisation on the nitrogen compounds of timothy
}

\author{
Terttu Ettala and Matti Kreula \\ Biochemical Research Institute, Kalevankatu 56 B, 00180 Helsinki 18, Finland \\ HILKKA TÄHTINEN \\ Agricultural Research Centre, Department of Agricultural Chemistry and Physics, \\ SF-01300 Vantaa 30
}

\begin{abstract}
The effect of sulphur deficiency and sulphur fertilisation on the nitrogen compounds of plants was studied, using timothy as the test species. The samples were obtained from 4 field trials performed in northern Finland. The nitrogen and sulphur treatments in each of these trials were as follows: a) $\mathrm{N} \mathrm{O}, \mathrm{S} \mathrm{O}$, b) $\mathrm{N} 48, \mathrm{~S} \mathrm{O}, \mathrm{c}) \mathrm{N} 48$, S 34, d) N 96, S O and e) N 96, S $68 \mathrm{~kg} /$ ha. Nitrogen was applied as NPK compound fertiliser and sulphur in the form of gypsum. In trials 1 and 2 sulphur given in addition to nitrogen increased the yield considerably.

The contents of soluble-, protein-, $a$-amino-, ammonium- and nitrate-nitrogen, as well as the free and peptide- and protein-bound amino acids were determined in the harvested timothy.

Nitrogen fertilisation did not have any noticeable effect on the protein-nitrogen content of sulphur-deficient plants, but sulphur fertilisation increased it by an average of $26 \%$ (trial 2). The proportion of soluble nitrogen of the total nitrogen in trials 1 and 2 averaged $50 \%$ with $\mathrm{N}$-fertilisation and $37 \%$ with $\mathrm{N}+\mathrm{S}$ fertilisation. Sulphur fertilisation decreased the contents of a-amino-, ammonium- and nitrate-nitrogen, and also their proportions of the total nitrogen. In those trials ( 3 and 4 ) in which sulphur fertilisation did not increase the yield, the proportion of soluble nitrogen of the total nitrogen was an average of $33 \%$ with all treatments.

In sulphur-deficient timothy the content of asparagine and aspartic acid totalled $60 \%$ of the content of free amino acids, and their nitrogen formed about $17 \%$ of the total plant nitrogen. The corresponding figures with sulphur fertilisation were $39 \%$ and $3.5 \%$, and in those trials where there was no sulphur deficiency (trials 3 and 4 ) on average $27 \%$ and $2.5 \%$, irrespective of fertilisation.

The proportion of soluble nitrogen of the total nitrogen of timothy was closely correlated $\left(\mathrm{r}=0.79^{* * *}\right)$ to the $\mathrm{N} / \mathrm{S}$ ratio, as was the proportion of asparagine plus aspartic acid of the total free amino acids $\left(r=0.91^{* * *}\right)$.
\end{abstract}

\section{Introduction}

In a series of experiments performed in northern Finland (PohjoisPohjanmaa and Kuusamo) by the Institute of Agricultural Chemistry and Physics, Agricultural Research Centre, two fields out of five showed much larger yields of timothy per hectare when sulphur was applied as well as nitrogen 
than when nitrogen was applied alone. Sulphur was applied as gypsum (17\% $\mathrm{S})$ and nitrogen as compound fertiliser $(\mathrm{N}: \mathrm{P}: \mathrm{K}: \mathrm{S}$ 12.0: $6.5: 14.9: 0)$. The average increase in the yield varied between 16 and $140 \%$. In these experiments the N/S ratio in timothy was much greater in plants which had suffered from sulphur deficiency and had been given nitrogen fertilisation than in plants which had obtained adequate sulphur (TÄHTINEN 1976, 1977).

As the sulphur-containing amino acids are important protein amino acids, it seemed probable that in sulphur-deficient timothy the protein content would be low in spite of the high nitrogen content. In green-house experiments several investigators have observed that sulphur deficiency does not prevent the incorporation of inorganic nitrogen into organic compounds, but it does restrict the protein synthesis of the plant and thus causes an accumulation of nonprotein nitrogen (Mertz et al. 1952, 1956, Stewart and Porter 1969, Aulakh et al. 1976, RENDIG et al. 1976). Most of the studies have been performed with alfalfa, corn and wheat. Studies on hay plants have been fewer (Cowling et al. 1971, BAKEr et al. 1973, Bolton et al. 1976), so that the timothy samples obtained from the above-mentioned field experiments provided interesting material for the study of the effect of sulphur deficiency and sulphur fertilisation on the nitrogen compounds of timothy in Finland.

\section{Materials and methods}

The material investigated derived from the hay trials reported in Table 1. In trials 1 and 2, also samples from 1969 were analysed besides the ones mentioned in the table. The hay was harvested at the start of flowering. The fertilisation and growth conditions, yield, total nitrogen and total sulphur contents have been reported on earlier (TÄHTINEN 1977).

The contents of soluble nitrogen, protein-, ammonium-, $a$-amino- and nitrate-nitrogen were determined in all the hay samples, and the contents

Table 1. Hay yields obtained from timothy stands in different trials (TÄHTINEN 1977).

\begin{tabular}{|c|c|c|c|c|c|c|c|c|}
\hline \multirow{3}{*}{$\begin{array}{l}\text { Treatment } \\
\left.\qquad \mathbf{N}^{\mathbf{1}}\right)\end{array}$} & \multirow{3}{*}{$\begin{array}{c}\mathrm{kg} / \mathrm{ha} \\
\left.\mathrm{S}^{2}\right)\end{array}$} & \multicolumn{7}{|c|}{ Hay yield $\mathrm{kg} / \mathrm{ha}$} \\
\hline & & \multicolumn{2}{|c|}{ Trial 1} & \multicolumn{2}{|c|}{ Trial 2} & \multicolumn{2}{|c|}{ Trial 3} & \multirow{2}{*}{$\frac{\text { Trial } 4}{1970}$} \\
\hline & & 1970 & 1971 & 1970 & 1971 & 1970 & 1971 & \\
\hline 0 & 0 & 955 & 1100 & 1785 & 1010 & 2335 & 1215 & 4305 \\
\hline 48 & 0 & 1960 & 2910 & 1700 & 1285 & 5635 & 3715 & 5935 \\
\hline 48 & 34 & 2085 & 3760 & 4095 & 2850 & 5645 & 3560 & 5840 \\
\hline 96 & 0 & 2265 & 3600 & 3050 & 2135 & 6565 & 5850 & 6670 \\
\hline 96 & 68 & 2515 & 4160 & 4920 & 5350 & 6630 & 5760 & 6495 \\
\hline \multicolumn{9}{|c|}{ Significance: } \\
\hline \multicolumn{2}{|c|}{ NPK level } & $* *$ & $*$ & $* * *$ & $* * *$ & $* * *$ & $* * *$ & $* *$ \\
\hline \multicolumn{2}{|c|}{ S-fertilisation } & $(*)$ & $* *$ & $* * *$ & $* * *$ & - & - & - \\
\hline \multicolumn{2}{|c|}{$\mathrm{NPK} \times \mathrm{S}$ interaction } & - & - & - & - & - & - & - \\
\hline
\end{tabular}

1) as multinutrient fertiliser

2) as gypsum. In trials 1 and 2, S applied twice in 1969 and 1970 
of free amino acids and the amino acids of the peptide and protein fractions in part of the samples.

The nitrogen determinations were performed by the Kjeldahl method with $\mathrm{KMnO}_{4}$ according to BEET (1955), and the sulphur determinations by the method of BIRD and Fountain (1970). For determining the soluble nitrogen, the dried sample was extracted for $3 \mathrm{~min}$ with $10 \%$ trichloracetic acid using an MSE 150 PG 100 Ultrasonic Disintegrator. After this the mixture was filtered and washed with $10 \%$ trichloracetic acid. The nitrogen in the filtrate obtained (= soluble nitrogen) was determined according to BEET, and ammonium nitrogen using an ammonia electrode, model 95-10, Orion Research Inc. On some samples nitrate nitrogen was determined with a nitrate ion electrode, model 93-07, Orion Research Inc. $a$-amino nitrogen in the filtrate was determined according to MütING and KaISER (1963).

The free amino acid fraction was separated from the filtrate with Amberlite IR 120 cation exchange resin in $\mathrm{H}^{+}$form, and analysed quantitatively. The residue (= filtrate minus free amino acids) was hydrolysed $(6 \mathrm{~N} \mathrm{HCl}, 20 \mathrm{~h}$, $106^{\circ} \mathrm{C}$, under nitrogen) and the liberated amino acids (= so-called peptide amino acids) were separated with Amberlite IR 120 resin and analysed quantitatively. The residue, that is the material insoluble in $10 \%$ trichloracetic acid, was hydrolysed as before, the amino acids (= protein amino acids) were separated from the hydrolysate with Amberlite and were analysed quantitatively. The amino acid determinations were performed using a Bio Cal BC 201 amino acid analyser.

Amides were included in the free amino acid fractions; in the amino acid determinations asparagine and threonine, and in some cases also serine, overlapped. Therefore parallel runs on partly hydrolysed $\left(1 \mathrm{~N} \mathrm{HCl}, 4 \mathrm{~h}, 106^{\circ} \mathrm{C}\right)$ free amino acid fractions, in which asparagine had been converted to aspartic acid, were performed. The hydrolysis of the protein fraction caused the complete decomposition of tryptophan, and the partial decomposition of sulphurcontaining amino acids. However, the results are regarded as valid for the intercomparison of the samples.

\section{Results}

The proportions of protein- and non-protein-nitrogen in timothy at the different rates of fertilisation are presented in Table 2 ; mean values for the three years of each trial are given. The figures from trials 1 and 2 , in which the sulphur fertilisation increased the hay yield, are given separately, and those from trials 3 and 4 , in which sulphur did not have any effect on the yield, are combined.

When nitrogen fertilisation was used without sulphur, the total nitrogen content of timothy increased in all trials, but in spite of this the proportion of protein nitrogen of the total nitrogen in the plants in sulphur-deficient plots decreased. This was most obvious in trial 2 , in which the effect of sulphur on the yield as well was highly significant (Table 1). In this trial the total nitrogen content of non-fertilised timothy was $1.66 \%$ of the dry matter. When the fertilisation provided $48 \mathrm{~kg}$ nitrogen per hectare the figure was $2.09 \%$, 
and with double $\mathrm{N}$-fertilisation $1.99 \%$. The corresponding protein nitrogen contents were $0.83 \%, 0.83 \%$ and $0.84 \%$ of the dry matter respectively, and so the proportions of the protein nitrogen of the total nitrogen were $50.0 \%$, $39.7 \%$ and $42.2 \%$. The proportion of soluble nitrogen with $\mathrm{N}$-fertilisation alone was then about $60 \%$ of the total nitrogen. When $34 \mathrm{~kg}$ sulphur per hectare was given in addition to nitrogen $(48 \mathrm{~kg} / \mathrm{ha})$, the total nitrogen content of timothy was $1.60 \%$ and that of protein nitrogen $1.02 \%$. With double fertilisation the corresponding figures were $1.78 \%$ and $1.10 \%$. The increase caused by sulphur fertilisation compared with nitrogen fertilisation alone was on the average $26 \%$. The proportion of protein nitrogen of the total nitrogen with $\mathrm{N}+\mathrm{S}$ fertilisation was on the average $63 \%$, and that of soluble nitrogen $37 \%$, of the total nitrogen. As to the soluble nitrogen, mainly the contents of $a$-amino and ammonium-nitrogen were decreased, as were their proportions of the total nitrogen.

In trials 3 and 4 , in which the yield did not increase after sulphur fertilisation, the proportion of the protein nitrogen with all the treatments was $67 \%$ $(65.0-68.0 \%)$ and that of soluble nitrogen averaged $33 \%$ of the total nitrogen.

The effect of $\mathrm{N}$ and $\mathrm{N}+\mathrm{S}$ applied to sulphur-deficient and sulphursufficient soils on the free amino acids of timothy is presented in Table 3 . The free amino acids were determined on the samples from 1970 and 1971 of trial 2 and from the 1970 samples of trials 3 and 4 . In plants which had grown

Table 2. Effect of sulphur fertilisation on the distribution of nitrogen in timothy and on its total nitrogen content and $\mathrm{N} / \mathrm{S}$ ratio.

\begin{tabular}{|c|c|c|c|c|c|c|c|c|c|}
\hline \multicolumn{2}{|c|}{ Fertilisation $\mathrm{kg} / \mathrm{ha}$} & \multirow{2}{*}{$\begin{array}{l}\text { Tot. N } \\
\% / \mathrm{dm}\end{array}$} & \multirow[t]{2}{*}{ Prot. N } & \multirow{2}{*}{$\begin{array}{l}\text { Sol. N } \\
\% \text { of }\end{array}$} & \multirow{2}{*}{\multicolumn{2}{|c|}{$\begin{array}{l}a-\mathrm{NH}_{2}-\mathrm{N} \mathrm{NH}_{4}-\mathrm{N} \\
\text { total nitrogen }\end{array}$}} & \multirow[t]{2}{*}{$\mathrm{NO}_{3}-\mathrm{N}$} & \multirow{2}{*}{$\begin{array}{l}\text { Tot. S } \\
\% / \mathrm{dm}\end{array}$} & \multirow{2}{*}{$\begin{array}{l}\mathrm{N} / \mathrm{S} \\
\text { ratio }\end{array}$} \\
\hline $\mathrm{N}$ & $\mathrm{S}$ & & & & & & & & \\
\hline \multicolumn{10}{|l|}{$\begin{array}{l}\text { Trial } 1 \\
\qquad(\mathrm{n}=3)\end{array}$} \\
\hline 0 & 0 & 1.32 & 61.4 & 38.6 & 8.4 & 3.1 & - & 0.10 & 13.1 \\
\hline 48 & 0 & 1.59 & 58.5 & 41.5 & 10.1 & 5.1 & - & 0.10 & 16.0 \\
\hline 96 & 0 & 1.95 & 53.8 & 46.2 & 11.7 & 5.0 & - & 0.11 & 18.7 \\
\hline 48 & 34 & 1.65 & 61.8 & 38.2 & 9.0 & 3.6 & - & 0.12 & 13.7 \\
\hline 96 & 68 & 1.69 & 64.5 & 35.5 & 8.3 & 3.3 & - & 0.13 & 13.3 \\
\hline \multicolumn{10}{|l|}{$\begin{array}{l}\text { Trial } 2 \\
\qquad(\mathrm{n}=3)\end{array}$} \\
\hline 0 & 0 & 1.66 & 50.0 & 50.0 & 15.1 & 6.2 & 2.3 & 0.10 & 17.1 \\
\hline 48 & 0 & 2.09 & 39.7 & 60.3 & 17.8 & 7.5 & 2.3 & 0.09 & 17.8 \\
\hline 96 & 0 & 1.99 & 42.2 & 57.8 & 16.9 & 6.6 & 3.4 & 0.08 & 24.8 \\
\hline 48 & 34 & 1.60 & 63.7 & 36.3 & 10.4 & 3.9 & 1.9 & 0.12 & 13.6 \\
\hline 96 & 68 & 1.78 & 61.8 & 38.2 & 11.1 & 4.4 & 2.8 & 0.14 & 12.4 \\
\hline \multicolumn{10}{|c|}{$\begin{array}{l}\text { Trials } 3 \text { and } 4 \\
\qquad(\mathrm{n}=3)\end{array}$} \\
\hline 0 & 0 & 1.22 & 67.2 & 32.8 & 7.3 & 4.1 & 6.3 & 0.13 & 9.7 \\
\hline 48 & 0 & 1.37 & 65.0 & 35.0 & 7.4 & 4.4 & 2.7 & 0.12 & 11.7 \\
\hline 96 & 0 & 1.69 & 68.0 & 32.0 & 8.5 & 5.4 & 2.0 & 0.14 & 12.4 \\
\hline 48 & 34 & 1.48 & 67.6 & 32.4 & 7.8 & 4.2 & 2.1 & 0.13 & 11.2 \\
\hline 96 & 68 & 1.65 & 66.7 & 33.3 & 7.4 & 4.5 & 2.3 & 0.14 & 12.1 \\
\hline
\end{tabular}


Table 3. Free amino acids in timothy grown with and without applications of nitrogen and sulphur.

\begin{tabular}{|c|c|c|c|c|c|c|}
\hline \multirow[b]{2}{*}{ Fertilisation } & \multicolumn{3}{|c|}{ Trial $2(1970-1971)$} & \multicolumn{3}{|c|}{ Trials 3 and 4 (1970) } \\
\hline & - & $\mathrm{N}$ & $\mathrm{N}+\mathrm{S}$ & - & $\mathrm{N}$ & $\mathrm{N}+\mathrm{S}$ \\
\hline Tot. N \%/dm & 1.7 & 2.0 & 1.9 & 1.3 & 1.5 & 1.6 \\
\hline $\begin{array}{l}\mathrm{NH}_{2}-\mathrm{N} \% / \text { tot. } \mathrm{N} \\
\text { Amino acids }\end{array}$ & 14.7 & 16.4 & 8.0 & 6.0 & 7.9 & 7.6 \\
\hline $\mathrm{g} / \mathrm{kg} \mathrm{dm}$ & 16.4 & 28.0 & 16.0 & 9.1 & 7.0 & 7.8 \\
\hline
\end{tabular}

Weight- $\%$ of the total amount of free amino acids

\begin{tabular}{|c|c|c|c|c|c|c|}
\hline 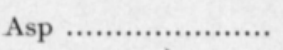 & 19.1 & 35.3 & 22.5 & 5.0 & 6.3 & 7.1 \\
\hline Ans + Thr $\mid \ldots \ldots$. & 23.7 & 25.1 & 16.7 & 15.4 & 20.1 & 20.9 \\
\hline Ser $\quad\} \ldots \ldots$. & & 1.7 & 3.3 & & 2.2 & \\
\hline Glu ........................ & 3.8 & 4.5 & 4.9 & 3.9 & 4.6 & 4.3 \\
\hline Pro ........................... & 36.3 & 18.1 & 30.5 & 46.3 & 37.5 & 40.9 \\
\hline Gly ........................ & 0.6 & 0.4 & 0.6 & 0.6 & 0.8 & 0.7 \\
\hline Ala ......................... & 3.4 & 2.9 & 3.8 & 4.4 & 4.6 & 4.1 \\
\hline Val ........................... & 2.9 & 1.9 & 3.1 & 4.1 & 4.8 & 4.1 \\
\hline Ile ......................... & 1.3 & 0.9 & 1.9 & 2.2 & 2.3 & 2.2 \\
\hline Leu ......................... & 0.7 & 0.4 & 0.9 & 1.3 & 1.7 & 1.3 \\
\hline Tyr ......................... & 0.5 & 0.4 & 0.7 & 1.1 & 0.8 & 0.6 \\
\hline Glu (Cys-Gly) ....... & 0.9 & 2.9 & 2.2 & 4.2 & 3.7 & 4.3 \\
\hline$\gamma \mathrm{Abu}$ & 2.2 & 1.9 & 2.4 & 4.2 & 4.1 & 3.5 \\
\hline Met .......................... & 0 & 0.2 & 0.4 & 0.5 & 0.5 & 0.4 \\
\hline Çys ......................... & 0.2 & 0.1 & 0.2 & 0 & 0.6 & 0 \\
\hline Phe .......................... & 15 & 1.0 & 2.1 & 1.1 & 2.0 & 1.9 \\
\hline Arg .......................... & 0.5 & 0.8 & 0.7 & 0.7 & 1.3 & 0.9 \\
\hline BAla ........................ & 0.4 & 0.3 & 0.3 & 0.6 & 0.3 & 0.4 \\
\hline 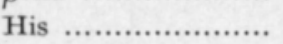 & 0.5 & 0.5 & 0.9 & 0.5 & 0.5 & 0.5 \\
\hline Lys ............................ & 0.6 & 0.5 & 0.7 & 0.9 & 1.3 & 1.1 \\
\hline 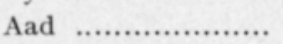 & 0.2 & 0.2 & 0.3 & 0.2 & 0.2 & 0.3 \\
\hline GlcN ...................... & 1.0 & 1.0 & 1.0 & 2.8 & 1.4 & 1.2 \\
\hline Orn .......................... & 0.2 & 0.2 & 0.4 & + & + & 0.1 \\
\hline
\end{tabular}

on sulphur-deficient soil, the total amount of free amino acids was greater than in plants which had received sulphur. The difference is mainly due to asparagine and asparatic acid, the combined amount of which, in plants growing on sulphurdeficient soil (trial 2), was $17 \mathrm{~g}$ per kg dry matter with $\mathrm{N}$-fertilisation alone and $6 \mathrm{~g}$ per $\mathrm{kg}$ with $\mathrm{N}+\mathrm{S}$ fertilisation. The corresponding amounts from trials 3 and 4 averaged 1.8 and $2.3 \mathrm{~g}$ per $\mathrm{kg}$. Of the total free amino acids, the proportion of asparagine plus aspartic acid in trial 2 with $\mathrm{N}$-fertilisation was $60.6 \%$ and with $\mathrm{N}+\mathrm{S}$ fertilisation $47.3 \%$. In trials 3 and 4 the corresponding figures were $25.3 \%$ and $28.8 \%$. Of the total nitrogen of timothy, the proportion of nitrogen in asparagine plus aspartic acid in trial 2 was about $17 \%$ with $\mathrm{N}$-fertilisation, $3.5 \%$ with $\mathrm{N}+\mathrm{S}$ fertilisation and in trials 3 and 4 on average $2.5 \%$, independent of fertilisation. The free amino acid composition was not related to the rate of application of fertiliser $(48 \mathrm{~N} / 34 \mathrm{~S}$ or $96 \mathrm{~N} / 68 \mathrm{~S})$, so that the results could be pooled (Table 3 ). The amounts of free cystine, methionine and glutathionine were small in all trials, with no clear differences between treatments. 
Besides free amino acids, the soluble nitrogen fraction contains nitrateand ammonium-nitrogen, and other compounds such as peptides and nucleotides. In sulphur deficiency, the nitrogen content of this "peptiden fraction rose with $\mathrm{N}$-only fertilisation. When this fraction was hydrolysed, the total amount of the amino acids obtained was slightly greater in sulphur-deficient than in sulphur-fertilised plants; in both more than $50 \%$ of the total amino acids was glutamic acid (Fig. 1).

The proportion of soluble nitrogen of the total nitrogen of timothy was correlated $\left(\mathrm{r}=0.79^{* * *}\right)$ to the $\mathrm{N} / \mathrm{S}$ ratio (Fig. 2). Also the proportion of asparagine plus aspartic acid of the total free amino acids was closely correlated $\left(\mathrm{r}=0.91^{* * *}\right.$ ) to the $\mathrm{N} / \mathrm{S}$ ratio (Fig. 3).

In the protein fraction, the amino acids of which were determined on the 1970 samples of trial 2, there appeared to be more aspartic acid in sulphurdeficient plants than in plants which had received sulphur (Fig. 1).

\section{Discussion}

In each trial the total nitrogen content of timothy increased after $\mathrm{N}$-fertilisation, being the highest in plants suffering from sulphur deficiency (TÄHTINEN 1977). In spite of the high total nitrogen content the protein nitrogen content was lower with $\mathrm{N}$-fertilisation alone than with $\mathrm{N}+\mathrm{S}$ fertilisation. The

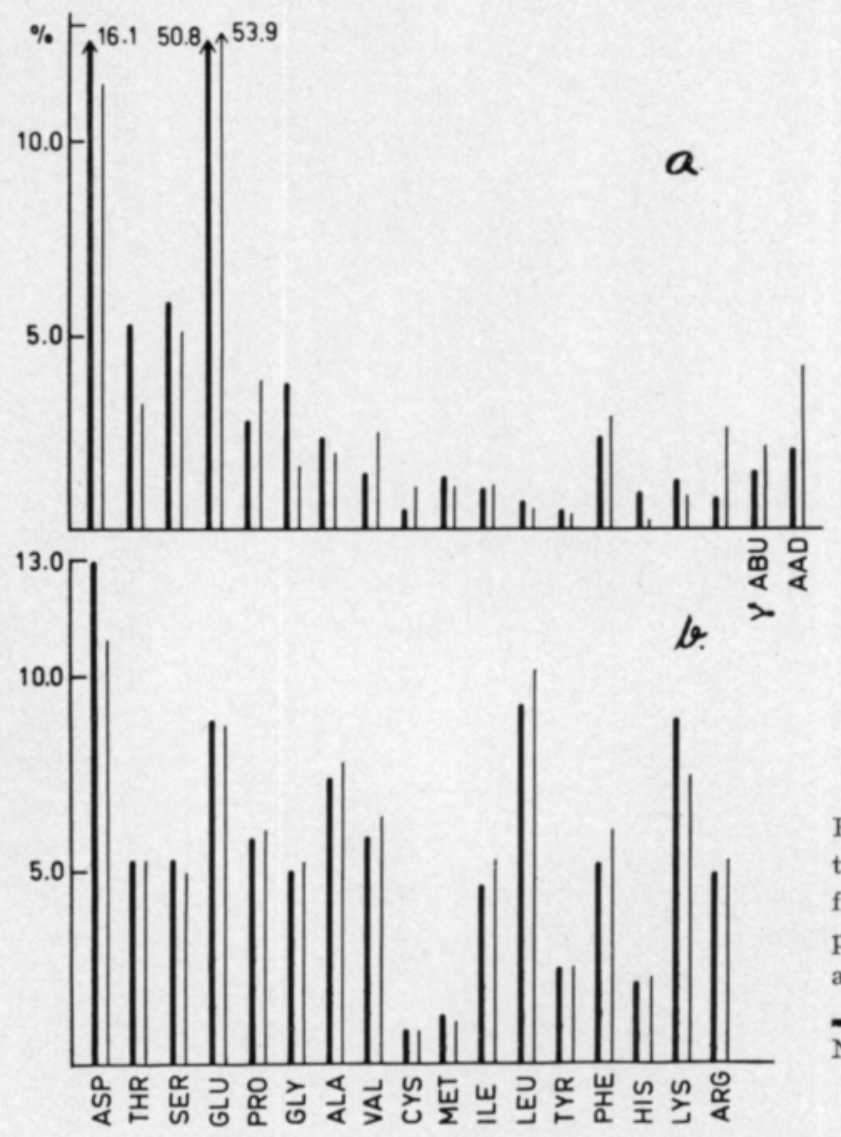

Fig. 1. Amino acid composition in timothy of a) peptide fraction and b) protein (weight per cent of the total amino acid in the hydrolysate) $\overline{\mathrm{N}+\mathrm{S}}$ fertilisation. 
Fig. 2. Correlation between soluble nitrogen of the total nitrogen of timothy and the $\mathrm{N} / \mathrm{S}$ ratio (coefficient $\mathrm{r}=$ $\left.0.79^{* * *}\right)$.

Fig. 3. Correlation between free aspartic acid plus asparagine of the total free amino acids of timothy and the N/S ratio (coefficient $\mathrm{r}=0.91^{* * *}$ ).
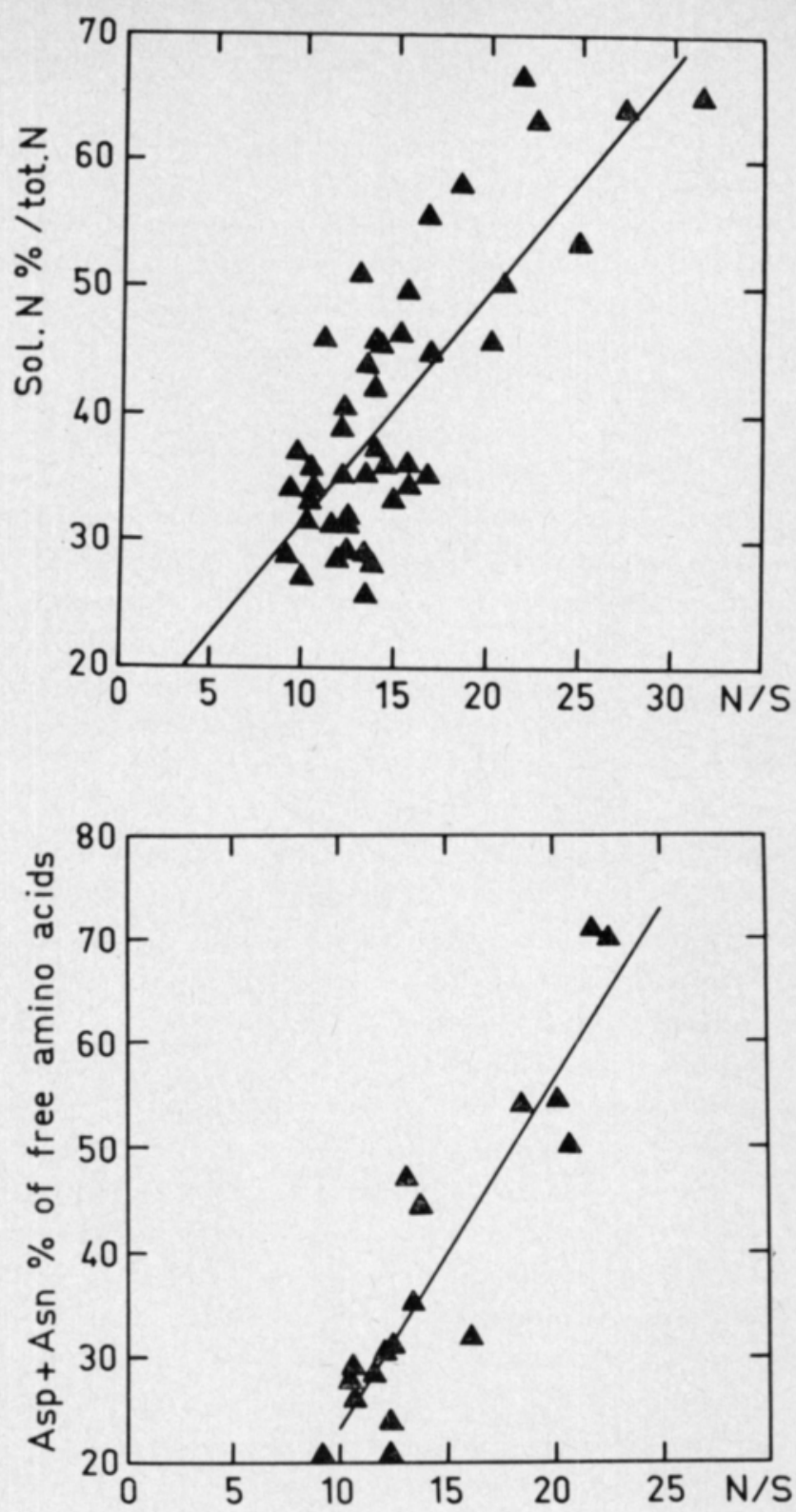

increase caused by the nitrogen fertilisation was due to the increase in the soluble nitrogen in the plants. The increase was greatest in the amount of organic non-protein nitrogen, but also the amounts of ammonium- and nitratenitrogen increased. Thus the field experiments with timothy showed that also under these conditions sulphur deficiency restricted protein synthesis and caused an accumulation of organic non-protein nitrogen in plants. In greenhouse experiments, accumulation of non-protein nitrogen caused by sulphur deficiency has been found in alfalfa (Mertz et al. 1952, Mertz and Matsumoto 1956, AUlakH 1976), corn (RENDig et al. 1976), wheat and beans (Stewart and Porter 1969). 
In our studies the proportion of free asparagine plus aspartic acid in timothy was $60 \%$ of the total free amino acids with $\mathrm{N}$-only fertilisation in sulphurdeficient areas, whereas in trials 3 and 4 , in which sulphur fertilisation did not increase the yield, the proportion averaged only $27 \%$. In sulphur deficiency both arginine and asparagine increase in alfalfa (MERTZ 1952), asparagine in leguminous plants, glutamine and arginine in tomatoes, asparagine and glutamine in barley, and arginine in white clover and flax (Coleman 1957), arginine and glutamic and aspartic acids in orchard grass (ADAMS and SHEARD 1966) and asparagine in perennial ryegrass (BoLton et al. 1976).

In timothy at all rates of $\mathrm{N}$ and $\mathrm{S}$ fertilisation there was a large amount of free proline. It had been observed earlier at the Biochemical Research Institute that large amounts of free proline are present in timothy (unpublished data). This is probably the result of the hay having been harvested at the flowering stage: it is known that pollen contains large amounts of free proline.

With sulphur fertilisation the total nitrogen content of timothy decreased. This is probably a dilution effect arising from the increase in the yield after application of sulphur (TÄHTINEN 1977). In contrast, sulphur caused an increase in the protein nitrogen content, and the non-protein nitrogen content decreased, in the trials ( 1 and 2 ) in which the yield did not improve after sulphur fertilisation. BAKER et al. (1973) have observed in their field experiments with orchard grass that non-protein nitrogen and nitrate-nitrogen decreased as a result of sulphur fertilisation. In the present study, the proportions of asparagine and asparatic acid of the total amounts of free amino acids also decreased under the effect of sulphur. In spite of this, with sulphur fertilisation, the amounts and proportions of the soluble nitrogen and $a$-amino nitrogen, as well as the amounts of free aspartic acid and asparagine, were higher in trial 2 than in trials 3 and 4 . Whether this is due to a slight sulphur deficiency in relation to nitrogen is difficult to say. The differences were the most obvious in 1970 , when the total nitrogen contents in trial 2 were exceptionally high.

In TÄHTINEN's (1977) study, the increase in yield caused by sulphur appeared to be related more to the $\mathrm{N} / \mathrm{S}$ ratio than to the sulphur content of the timothy crop. In the present study, the N/S ratio appeared to be a good measure for the quality of nitrogen compounds in the timothy, too. The proportion of soluble nitrogen of the total nitrogen of timothy, and also the proportion of free asparagine and aspartic acid of the total free amino acids, was directly proportional to the N/S ratio. According to RENDIG et al. (1976) the N/S ratio in young maize is directly proportional to the amide nitrogen, and a high amide nitrogen content is associated with a low content of reducing sugars. 


\title{
REFERENCES
}

Adams, C. A. \& Sheard, R. W. 1966. Alterations in the nitrogen metabolism of Medicago sativa and Dactylis glomerata as influenced by potassium and sulfur nutrition. Can. J. Pl. Sci. 46: $671-680$.

Aula Kh, M. S., Dev, G. \& Arora, B. R. 1976. Effect of sulphur fertilization on the nitrogensulphur relationship in alfalfa (Medicago sativa L. Pers.). Plant and Soil 45: 75-80.

Baker, A. S., Mortenson, W. P. \& Dormanis, P. 1973. The effect of N and S fertilization on the yield and quality of orchardgrass. Sulphur Inst. J. 9:14-16.

BEET, A. E. 1955. Potassium permanganate in the Kjeldahl method for the determination of nitrogen in organic substances. Nature 175: 513-514.

Bird, P. R. \& Fountain, R. D. 1970. A method for the determination of sulfur in some biological materials. Anal. 95: $98-102$.

Bolton, J., Nowakowski, T. Z. \& Lazarus, W. 1976. Sulphur-Nitrogen Interaction Effects on the Yield and Composition of the Protein-N, Non-protein-N and Soluble Carbohydrates in Perennial Ryegrass. J. Sci. Fd. Agric. 27: 553-560.

Coleman, R. G. 1957. The effect of sulphur deficiency on the free amino acids of some plants. Austr. J. Biol. Sci. 10: 50-56.

Cowling, D. W. \& Jones, L. H. P. 1971. Sulphur deficiency of two forage plants in England. Sulphur Inst. J. 6: 8-13.

Mertz, E. T., Singleton, V. L. \& Garey, C. L. 1952. The effect of sulfur deficiency on the amino acids of alfalta. Arch. Biochem. Biophys. 38: 139-145.

$\ldots-\&$ Matsumoto, H. 1956. Further Studies on the Amino Acids and Proteins of SulfurDeficient Alfalfa. Arch. Biochem. Biophys. 63: 50-63.

MÜrING, D. \& KAISER, E. 1963. Zur quantitativen Bestimmung von $a$-Amino-Stickstoff in biologischen Material mittels der Ninhydrin-Reaktion. Hoppe-Seyler's Z. Physiol. Chem. 332: 276-281.

Rendig, V. V., Oputa, C. \& Mc Сомв, E. A. 1976. Effects of sulfur deficiency on non-protein nitrogen, soluble sugars, and N/S ratios in young corn (Zea Mays L.) plants. Plant and Soil 44: 423-437.

Stewart, B. A. \& Porter, L. K. 1969. Nitrogen-Sulfur Relationship in Wheat (Triticum aestivum L.), Corn (Zea mays) and Beans (Phaseolus vulgaris). Agron. J. 61: 267-271.

TÄHTINEN, H. 1976. Rikin merkitys timotein lannoituksessa. Koetoim. ja Käyt. 28. 12. $1976: 47$.

$\ldots-1977$. The effect of sulphur on the yield and chemical composition of timothy. Ann. Agric. Fenn. 16: 220-225.

Ms received March 15, 1978

\section{SELOSTUS}

\section{Rikkilannoituksen ja rikin puutteen vaikutus timotein typpiyhdisteisiin}

\author{
Terttu Etrala ja Matti Kreula \\ Biokemiallinen Tutkimuslaitos, Kalevankatu 56 B, 00180 Helsinki 18 \\ HILKKA TÄHTINEN \\ Maatalouden tutkimuskeskus, Maanviljelyskemian ja -fysiikan laitos, 01300 Vantaa 30
}

Rikin puutteen ja rikkilannoituksen vaikutusta kasvien typpiyhdisteisiin on tutkittu timoteiheinästä. Tutkittavat näytteet on saatu Maatalouden Tutkimuskeskuksen Maanviljelyskemian- ja fysiikan laitoksen Pohjois-Suomessa suorittamista kenttäkokeista. Typpi- ja rikkilannoitus on näissä kokeissa ollut seuraava: a) $\mathrm{N} \mathrm{O}, \mathrm{S} \mathrm{O}, \mathrm{b}) \mathrm{N} \mathrm{48,} \mathrm{S} \mathrm{O} \mathrm{kg/ha,} \mathrm{c)} \mathrm{N} 48, \mathrm{~S} 34$ kg/ha, d) N 96, S O kg/ha ja e) N 96, S 68 kg/ha. Rikki annettiin kipsinä $(17.0 \%$ S) ja typpi Y-lannoksena (N :P : K : S $12.0: 6.5: 14.9: 0$ ). Kahdessa koesarjassa viidestä (kokeet 1 ja 2) typen ohella annettu rikkilannoitus on lisännyt satoa huomattavasti. 
Kasveista määritettiin liukeneva typpi, proteiini-, $a$-amino-, ammonium- ja nitraattityppi sekä vapaat, peptidi- ja proteiinifraktion aminohapot.

Liukenevan typen osuus timotein kokonaistypestä on ollut suorassa suhteessa $\left(\mathrm{r}=0,79^{* * *}\right)$ $\mathrm{N} / \mathrm{S}$-suhteeseen samoin kuin asparagiinin ja asparagiinihapon osuus vapaiden aminohappojen kokonaismäärästä $\left(\mathrm{r}=0,91^{* * *}\right)$.

Typpilannoitus ei ole oleellisesti vaikuttanut rikin puutteessa olleiden kasvien proteinityppipitoisuuteen, mutta rikkilannoitus on kohottanut sitä keskimäärin $26 \%$ (Koe 2). Liukenevan typen osuus kokonaistypestä on kokeissa 1 ja 2 N-lannoituksella ollut keskimäärin $50 \%$ ja N+S-lannoituksella $37 \%$. Rikkilannoituksella ovat $a$-amino-, ammonium- ja nitraattityppi, kuten myös niiden osuudet kokonaistypestä alentuneet. Kokeissa (3 ja 4), joissa rikkilannoitus ei ollut lisännyt satoa, on liukenevan typen osuus kokonaistypestä ollut kaikissa ryhmissä keskimäärin $33 \%$.

Rikin puutteessa olleissa kasveissa on asparagiinin ja asparagiinihapon yhteismäärä ollut $60 \%$ koko vapaiden aminohappojen määrästä ja niiden sisältämä typpi n. $17 \%$ timotein kokonaistypestä. Vastaavat luvut ovat rikkilannoituksella olleet $39 \%$ ja $3.5 \%$ ja kokeissa, joissa rikin puutetta ei ole ilmennyt (kokeet 3 ja 4) keskimäärin $27 \%$ ja 2,5 \% lannoituksesta riippumatta. 